\title{
Role of thalassemia screening in prevention and control of thalassemia - a 5 year experience
}

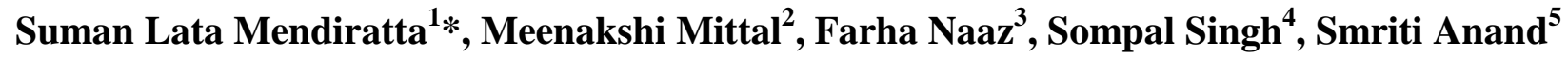 \\ ${ }^{1}$ Project Coordinator Thalassemia Control Program, North Delhi Municipal Corporation, Consultant Gynaecologist, \\ North DMC Medical College and Hindu Rao Hospital, New Delhi, India \\ ${ }^{2}$ CMO North DMC Medical College and Hindu Rao Hospital, New Delhi, India \\ ${ }^{3}$ Junior Resident, North DMC Medical College and Hindu Rao Hospital, New Delhi, India \\ ${ }^{4}$ Senior Pathologist North DMC Medical College and Hindu Rao Hospital, New Delhi, India \\ ${ }^{5}$ Department of Obstetrics and Gynaecology, North DMC Medical College and Hindu Rao Hospital, New Delhi, India
}

Received: 15 July 2016

Accepted: 10 August 2016

\section{*Correspondence:}

Dr. Suman Lata Mendiratta,

E-mail: sumanmendi@yahoo.co.in

Copyright: $\odot$ the author(s), publisher and licensee Medip Academy. This is an open-access article distributed under the terms of the Creative Commons Attribution Non-Commercial License, which permits unrestricted non-commercial use, distribution, and reproduction in any medium, provided the original work is properly cited.

\section{ABSTRACT}

Background: Thalassemia is a commonest genetic blood disorder in India which can be prevented by antenatal screening and prenatal diagnosis. Aim of the study was to screen antenatal women and their spouses to detect "couples at risk" of thalassemia major births and offering them genetic counseling and option of prenatal diagnosis thereby preventing the birth of thalassemia major babies.

Methods: Thalassemia screening for antenatal women was done by NESTROFT test and RBC Indices (MCV, MCH, and RBC count). Confirmation of diagnosis was done by HPLC test. Husbands of women testing positive on HPLC were also tested and couples at risk detected. They were counseled and referred for prenatal genetic diagnosis. Women carrying thalassemia major fetus were advised termination and those with normal and thalassemia minor fetus were advised to continue pregnancy.

Results: A total of 93871 patients were screened and HPLC was done on 10983 patients. 7.07\% had one or the other hemoglobinopathies and 5.8\% had beta thalassemia trait. Among antenatal beta thalassemia trait was found in 5.02\%, $\mathrm{HbD}$ in $0.36 \%, \mathrm{HbE}$ in $0.58 \%$ and $\mathrm{HbS} 0.05 \%$. Forty two "at risk couples" (both husband and wife thalassemia trait) were identified, 16 of these underwent prenatal diagnosis and 3 thalassemia major births were terminated.

Conclusions: Lack of awareness, late registration, husbands not coming/turning up for their test and "at risk couples" opting out of prenatal diagnosis are the cause of thalassemia major births which can be prevented if awareness is generated amongst masses, screening and prenatal genetic diagnosis services are made widely available.

Keywords: Thalassemia, HPLC, Patients

\section{INTRODUCTION}

Thalassemia is one of the commonest inherited blood disorders. According to WHO $4.5 \%$ of population is affected by thalassemia and allied disorders. In India 3$4 \%$ of population are carriers of $\beta$ thalassemia and 8000 to 10000 children are born every year with thalassemia major. ${ }^{1,2}$ Several studies from different regions have shown a high prevalence of thalassemia carriers in different populations. It varied between $0-17 \%$ in the population with a mean of nearly $4 \% .^{3}$ In various studies conducted by ICMR, the mean prevalence of $\beta$ thalassemia was found to be between $2.9 \%$ to $4.6 \% .^{3}$ In some areas the incidence of carrier state is higher due to consanguineous marriages in some communities. Control of thalassemia in India is a major problem due to ignorance about the disease, social, cultural and religious taboos and family influences. 
Birth rates of homozygous $\beta$ thalassemia have reduced considerably in different parts of the world. Cyprus, Sardinia Italy and Greece have been able to control thalassemia with their extensive screening programs at various levels along with prenatal diagnosis. Iran has an antenatal diagnostic program and it has reduced birth of Thalassemia major children. ${ }^{4}$ Therefore there is an urgent requirement for starting a thalassemia screening and control program at national level.

A thalassemia control program has been running in Hindu Rao Hospital of Delhi for last five years. Under this program screening of antenatal women is carried out to detect thalassemia carriers thereby detecting couples at risk, who are offered genetic counseling and option of prenatal diagnosis. Various other haemoglobinopathies have also been detected in the population under study. Data of five years has been compiled and is being presented.

\section{METHODS}

The study was undertaken in Hindu Rao Hospital of Municipal Corporation of Delhi from September 2008 to September 2013 after obtaining ethical clearance. The hospital acts as a referral centre for patients from all other hospitals, colony hospitals, and maternity homes under MCD. In hospitals, colony hospitals and maternity homes of MCD initial screening was done by Nestroft test or Complete blood count test depending on the facility available. Cut off criteria fixed for $\mathrm{CBC}$ were, $\mathrm{MCH}<27$ pg, MCV <80 fl, RBC count >5.0 million/cmm. All patients who were NESTROFT test positive or showing deranged parameters on CBC were referred to Hindu Rao Hospital for confirmation by HPLC test. Patients referred from other hospital and maternity homes for HPLC test were referred along with their spouses so that results for both were available together in case any intervention was required.

A $5 \mathrm{ml}$ intravenous blood sample was collected in EDTA vial. RBC indices were measured in an automated hematology counter. $\mathrm{HbA} 2, \mathrm{HbF}$ and other hemoglobin variants were quantitated by HPLC using the variant hemoglobin testing system (Bio-Rad laboratories). HbA2 level of $>3.5 \%$ is used as a cutoff for diagnosis of betathalassemia carriers.

The system also tests various other structural variants of hemoglobin. Spouses of antenatal women diagnosed with Beta thalassemia trait and other hemoglobinopathies were called for counseling and screening. Such spouses also undertake the HPLC test with a view to detect at risk couples where both partners are Thalassemia carriers. All such couples are referred to higher centre where facility for mutation studies and prenatal diagnosis is available. Mutation studies along with CVS or cordocentesis are performed to ascertain the thalassemia status of the fetus.

\section{RESULTS}

Table 1: Number of patients screened (year wise) from 2008-2013.

\begin{tabular}{|c|c|c|c|c|c|c|c|}
\hline Year & $\begin{array}{l}\text { Sept } 2008 \text { - } \\
\text { Dec } 2008\end{array}$ & $\begin{array}{l}\text { Jan } 2009= \\
\text { Dec } 2009\end{array}$ & $\begin{array}{l}\text { Jan } 2010 \text { - } \\
\text { Dec } 2010\end{array}$ & $\begin{array}{l}\text { Jan } 2011- \\
\text { Dec } 2011\end{array}$ & $\begin{array}{l}\text { Jan } 2012 \text { - } \\
\text { Dec } 2012\end{array}$ & $\begin{array}{l}\text { Jan } 2013- \\
\text { Sept } 2013\end{array}$ & Total Pts \\
\hline Patient screened & 677 & 14381 & 22977 & 26819 & 18473 & 10544 & 93871 \\
\hline $\begin{array}{l}\text { Screen positive patient } \\
\text { required HPLC }\end{array}$ & 162 & 1407 & 1657 & 2196 & 3216 & 2345 & 10983 \\
\hline $\begin{array}{l}\text { Haemoglobinopathy } \\
\text { detected on HPLC }\end{array}$ & 12 & 101 & 176 & 203 & 150 & 135 & 777 \\
\hline
\end{tabular}

Table 2: Overall distribution of hemoglobinopathies tested positive for thalassemia.

\begin{tabular}{|c|c|c|c|c|c|c|}
\hline Year & Hemoglobinopathies & Beta thal trait & Hb E & Hb D & $\mathrm{Hb} \mathrm{S}$ & Others \\
\hline 2008 & 12 & 12 & 0 & 0 & 0 & 0 \\
\hline 2009 & 101 & 90 & 8 & 1 & 2 & 0 \\
\hline 2010 & 176 & 156 & 15 & 4 & 1 & 0 \\
\hline 2011 & 203 & 176 & 17 & 8 & 3 & 0 \\
\hline 2012 & 150 & 116 & 18 & 14 & 0 & 2 \\
\hline 2013 & 135 & 91 & 12 & 15 & 10 & 6 \\
\hline Total & 777 & $641(82.4 \%)$ & $70(9.0 \%)$ & $42(5.4 \%)$ & $16(2.05 \%)$ & $8(1 \%)$ \\
\hline Prevalence & 7.07 & 5.84 & 0.63 & $0.38 \%$ & $0.14 \%$ & 0.07 \\
\hline
\end{tabular}

A total of 93871 patients were screened over a period of five years, out of these 10983 patients who were either
Nestroft test positive or were suspected thalassemia trait on CBC test underwent HPLC test for confirmation of 
diagnosis. Out of 10983 patients tested by HPLC over a period of five year, 70.4\% (7737 out of 10983) were antenatal women, and $29.6 \%$ (3246) belonged to other category which included unmarried females in premarital age group, spouses of women testing positive and children of school going age group tested as part of their school medical check-up. $84 \%$ of patients tested were Hindus and $16 \%$ were Muslims (Table 1).

Overall prevalence of various hemoglobinopathies amongst those tested by HPLC was found to be $7.07 \%$ (Table 2).
The distribution of various hemoglobinopathies is shown in (Table 3). $\beta$ thalassemia trait was found in $5.85 \%$ and $\mathrm{HB} \mathrm{E}$ in $0.67 \%$. Among various hemoglobinopathies $\beta$ thalassemia trait was the commonest, $82.4 \%$ had B thalassemia trait, whereas $9.0 \%$ had HB E trait, 5.4\% had $\mathrm{Hb} \mathrm{D}, 2.1 \%$ had sickle cell trait and $1 \%$ had other uncommon $\mathrm{Hb}$ variants. The prevalence of hemoglobinopathies among antenatal women was $6.05 \%$, the prevalence of $\mathrm{B}$ thalassemia trait was $5.02 \%$ and that of $\mathrm{Hb} \mathrm{E}$ was $0.58 \%$. $\mathrm{Hb} \mathrm{D}$ was found in $0.36 \%$ and $\mathrm{HbS}$ in $0.05 \%$ of antenatal women (Table 3 ).

Table 3: Distribution of hemoglobinopathies detected in antenatal women.

\begin{tabular}{|lllllll|}
\hline Antenatal women tested & Total hemoglobinopathies & B thal trait & Hb E & Hb D & Hb S & Others \\
\hline 7737 & 468 & 388 & 45 & 28 & 4 & 3 \\
\hline Prevalence & 6.049 & 5.015 & 0.58 & 0.36 & 0.05 & 0.038 \\
\hline
\end{tabular}

Table 4: Further prenatal genetic testing done in antenatal women tested positive for thalassemia.

\begin{tabular}{|lllll|}
\hline $\begin{array}{l}\text { Antenatal } \\
\text { patients tested }\end{array}$ & $\begin{array}{l}\text { Antenatal } \\
\text { patients tested positive }\end{array}$ & $\begin{array}{l}\text { Spouses } \\
\text { underwent HPLC }\end{array}$ & $\begin{array}{l}\text { "At risk couples" } \\
\text { detected }\end{array}$ & $\begin{array}{l}\text { Spouses did not } \\
\text { report/drop out }\end{array}$ \\
\hline 7737 & 468 & 272 & 42 & 196 \\
\hline Total couples & $\begin{array}{l}\text { Patient opted for genetic } \\
\text { testing }\end{array}$ & CVS done & $\begin{array}{l}\text { CVS not done due to } \\
\text { late preg. }\end{array}$ & CVS not reqd. \\
\hline 42 & 16 & 8 & 3 & 5 \\
\hline
\end{tabular}

HPLC was advised to husbands of 468 screen positive antenatal women to detect at risk couples, out of which husbands of only $272(58.2 \%)$ husbands reported for HPLC test in spite of repeated reminders. Out of these 272 husbands, 42 spouses were detected to be positive for $\beta$ Thalassemia trait, and these 42 at risk couples required prenatal diagnosis (Table 4). All these couples were counselled about the risk of birth of $\beta$ thalassemia major child and referred to other centres for CVS, since genetic testing is not available in our hospital. Out of these 26 couples were lost to follow up. Out of 16 couples who underwent prenatal diagnosis, CVS or cordocentesis could not be done in three cases due to advanced pregnancy. In another five it was decided that CVS was not required due to presence of uncommon $\mathrm{Hb}$ variants which do not carry much clinical significance in later life. CVS or cordocentesis was performed in eight cases. Of these four fetuses were diagnosed as $\beta$ thalassemia minor and one was normal, all these couples were advised to continue the pregnancy normally. Three antenatal women were found to be carrying thalassemia major fetus, all these pregnant women underwent termination of pregnancy.

\section{DISCUSSION}

Thalassemia is a traumatic disorder and inherited to next generation due to their parent's ignorance. Birth of Thalassemia major child can be prevented by carrier screening, premarital counseling, prenatal diagnosis and generating awareness amongst masses. Different countries have varied experience and no single strategy applies to all populations. Premarital screening is successful approach for thalassemia prevention but is not feasible in India because of social and cultural taboos and non-availability of screening and diagnostic services to large no of population residing in remote places and inaccessible health services. However in present women and couples who are at risk of having children with thalassemia major and other hemglobinopathies. Many studies have reported success of antenatal screening followed by prenatal diagnosis. 5,6

According to WHO, $4.5 \%$ of world's population is affected by thalassemia and allied disorders. Carrier rate of $\beta$ Thalassemia ranges from 1 to $17 \%$ in India with average of $3-4 \% .^{3}$ In our study the overall prevalence of hemoglobinopathies was found to be $7.07 \%$ and that of $\beta$ thalassemia trait to be $5.84 \%$. A few studies done earlier have shown that certain communities like the Sindhis, Kutchhi Bhanushalis and Punjabis from Western and Northern India have a high prevalence $(5-15 \%)$ of betathalassemia (Sukumaran, Mehta et al, Balgir). ${ }^{7,9}$ The first multicentre study was done by the Indian Council of Medical Research in the mid-1980s. In 1975, Sukumaran observed that $\beta$ thalassemia is the commonest inherited hemoglobin disorder in Indian subcontinent, $\mathrm{Hb} \mathrm{S}$ is more frequently observed in tribal populations, $\mathrm{Hb} \mathrm{E}$ in eastern region, $\mathrm{Hb} \mathrm{D}$ in Punjab and $\beta$ thalassemia trait to varying degrees in almost all population groups. ${ }^{7}$ High 
school children from Mumbai in the west, Delhi in the North and Kolkata in the East were studied by Madan et al, the prevalence of $\beta$ thalassemia trait was $2.7 \%$ in Mumbai, $5.5 \%$ in Delhi and $10.2 \%$ in Kolkata. ${ }^{2}$

In our study amongst antenatal women various types of hemoglobinopathies were found in $6.05 \%$ and $\beta$ thalassemia trait was found in $5.02 \%$ of women. In a study by Bukhanwala prevalence of $\beta$ thalassemia trait was found to be $3.38 \%$, whereas in a study conducted by Asha Baxi in Madhya Pradesh, 1006 pregnant women were tested, $\beta$ thalassemia trait was found in $2.78 \%$ and other hemoglobin variants in $0.69 \%$ women. ${ }^{10,11}$

$\mathrm{Hb} \mathrm{D}$ Punjab is seen mainly in North western India. In Surat, study by Bukhanvala reported 11 cases of $\mathrm{Hb} \mathrm{D}$ $(0.36 \%)$, while in our study prevalence of $\mathrm{Hb} \mathrm{D}$ was found to be $0.38 \%$ among the total study population and $0.36 \%$ in antenatal women. ${ }^{10}$ Madan et al found $\mathrm{Hb} \mathrm{D}$ in $1.10 \%$ in Delhi school children. ${ }^{2}$

$\mathrm{Hb} \mathrm{E}$ is widely distributed in North eastern states of india. ${ }^{12}$ Study by Bukhanwala reported $\mathrm{Hb} \mathrm{E}$ in $0.23 \%$, while in our study $\mathrm{Hb} \mathrm{E}$ was found in $0.63 \%$ of overall study group, which may be due to large number of migrants from northeastern states to Delhi. ${ }^{10}$ However in antenatal women $\mathrm{Hb} \mathrm{E}$ was found in $0.58 \%$. In a multicentric study by Mohanty et al in 2013 high prevalence of $\mathrm{Hb} \mathrm{E}$ was reported from DIbrugarh in Assam (23.9\%), whereas in Kolkata in West Bengal it was $3.92 \%{ }^{13}$ Madan et al reported $\mathrm{Hb} \mathrm{E}$ in $0.04 \%$ in Mumbai school children. ${ }^{2}$

Bhatia and Rao have reported the prevalence of sickle cell trait in tribal populations in south Gujarat, which ranges from 0 to $31.4 \% .^{14}$ In study by Bukhanwala prevalence of sickle cell trait was $1.5 \%$, Madan et al reported $\mathrm{Hb} \mathrm{S}$ in $0.16 \%$ in Mumbai. ${ }^{2,10}$ In our study it was $0.14 \%$ in total study population and $0.05 \%$ in antenatal women.

In our study most women were in second trimester of pregnancy. Late registration is one of the major hurdles in early detection of thalassemia trait and prenatal diagnosis. In our study CVS could not be performed in case of three women because of advanced pregnancy. Therefore early registration and early thalassemia screening in first trimester itself is crucial to prevent birth of thalassemia major child. Out of 468 positive antenatal women only $58.2 \%$ of the husbands could be tested, due to their failure to turn up for testing due to lack of awareness and inability to understand the importance of screening of both partners. Even in cases where the couples were counseled and referred to higher centre for prenatal diagnosis, only 16 out of 42 couples took the initiative to get their tests done. Similar results were observed in a study by Colah et al, 61935 pregnant women were tested, they detected hemoglobinopathies in 1233 women out of which 1020 were BTT and 213 were other hemoglobinopathies. ${ }^{5}$ In their study $69 \%$ of the husbands of positive patients could be tested. 37 couples were identified out of which only 15 couples underwent prenatal diagnosis. ${ }^{5}$ Non availability of prenatal genetic diagnostic facility at our set up was the cause of such poor compliance in addition to the lack of awareness amongst masses. This shows that there is a need for generating large scale awareness with help of medical and paramedical staff, media, social volunteers and parent organizations. In addition setting up of more genetic diagnostic labs in different parts of country also needs to be explored.

\section{CONCLUSION}

Thalassemia is a preventable single gene disorder. Thalassemia screening needs to be included in routine antenatal investigation protocol, all obstetricians should get thalassemia screening done as a mandatory test in antenatal along with routine hemoglobin testing to detect thalassemia trait and other hemoglobinopathies. The spouses of thalassemia trait women need to be counselled to get their HPLC test done to diagnose at risk couples and advised to undergo prenatal genetic diagnosis to ascertain thalassemia status of their babies thereby avoiding thalassemia births. As observed in our study thalassemia status of fetuses of many of the risk couples could not be known due to non-availability of prenatal genetic diagnosis services at our centre. Many couples did not get genetic testing done inspite of being referred to higher centres. Thus prenatal diagnostic tests should be made available at government hospitals free of cost so that the patients are motivated to undergo these tests without too much of hassle.

Since India is a developing country, it is not economical to do HPLC for mass screening of Beta thalassemia trait. It is advisable to use either NESTROFT or Red Cell indices or combination of the two tests for mass screening programs.

This study concludes that it is feasible to establish centres for awareness, screening and counseling in health centre, hospitals and other institutions where these facilities are not available and their linkages with higher centres for prenatal genetic testing can help in timely detection and thus prevention of birth of thalassemia major babies. Moreover screening programs also provide a platform for creating awareness and education for prevention of Thalassemia.

\section{Funding: No funding sources \\ Conflict of interest: None declared \\ Ethical approval: The study was approved by the Institutional Ethics Committee}

\section{REFERENCES}

1. Verma IC, Choudhary VP, Jain PK. Prevention of thalassemia: a necessity In India. Indian $\mathrm{J}$ pediatr. 1992;59:649-54. 
2. Madan N, Sharma S, Sood SK, Colah R, Bhatia HM. Frequency of beta-thalassemia trait and other hemoglobinopathies in northern and western India. India J Hum Genet. 2010;16(1)16-25.

3. Modell B, Petrou M. The problem of the hemoglobinopathies in India. Ind $\mathrm{J}$ Hematol. 1983;1:5-16.

4. Abolghasemi H, Amid A, Zeinali S, Radfar $\mathrm{MH}$, Esghi P, Rahimnejad MS, et al. Thalassemia in Iran: epidemiology, prevention and management. J Pediatr Hematol Oncol. 2007;29:223-8.

5. Colah R, Surve R, Wadia M, Solanki P, Mayekar P, Thomas M, et al. Carrier screening for B thalassemia during pregnancy in India: a 7 year evaluation. Genetic Testing. 2008;12(2):181-5.

6. Colah RB, Gorakshakar A, Surve E, Wadia M, Ghosh K, Mohanty D. Feasibility of antenatal screening of $\beta$-thalassemia in Mumbai, India. Acta Heamatol. 2001;105:252.

7. Sukumarn PK. Abnormal hemaglobins in India. In: Sen NN, Basu AK, editors. Trendes in hematology. Calcutta: Saraswati press; 1975.

8. Mehta BC, Dave VB, Joshi SR, Baxi AJ, Bhatia HM, Patel JC. Study of hematological and genetical characteristics of Cutchi Bhanushali community. Indian J Med Res. 1972;60:305-11.
9. Balgir RS. Spectrum of hemoglobinopathies in the state of Orissa, India; a ten years cohort study. JAPI. 2005;53:1021-6.

10. Bhukhanwala DS, Sorathiya SM, Sawant P, Colah R, Ghosh K, Gupte SC. Antenatal screening for identification of couples for prenatal diagnosis of severe hemoglobinopathies in Surat, South Gujrat. J Obstet Gynae India. 2013;63(2):123-7.

11. Baxi A, Manila K, Kadhi P, Heenaet B. Carrier screening for $\mathrm{B}$ thalassemia in pregnant Indian women. Experience at a single Centre in Madhya Pradesh. Indian journal of Hematology and Blood transfusion. 2013;29(2):71-4.

12. Sharma A. Hemoglobinopathies in India. In: peoples of India: some genetical aspects. New Delhi: ICMR; 1983:31-49.

13. Mohanty D, Colah RB, Gorakshakar AC, Patel RZ, Master DC, Mahanta J, et al. Prevalence of $\beta$ thalassemia and other haemoglobinopathies in six cities in India: a multicentre study. J Community Genet. 2013;4(1):33-42.

14. Bhatia HM, Rao VR. Genetic atlas of Indian tribes. Mumbai: Institute of Immunohaematology (ICMR); 1987.

15. Ghosh K, Colah R. Control and management of thalassemia and other hemoglobinopathies in the Indian Subcontinent-Synoptic Views. 2008:36.

Cite this article as: Mendiratta SL, Mittal M, Naaz F, Singh S, Anand S. Role of thalassemia screening in prevention and control of thalassemia - a 5 year experience. Int J Reprod Contracept Obstet Gynecol 2016;5:3107-11. 